\title{
Pos Gizi Remaja di SMA Negeri 12 Kota Jambi
}

\author{
Merita $^{1}$, Tri Kusuma ${ }^{2}$, Yolanda Wulan Sari ${ }^{3}$, Rahmadiani ${ }^{4}$, Wisa Amelia Futri ${ }^{5}$ \\ ${ }^{1}$ Program Studi Ilmu Gizi, Sekolah Tinggi Ilmu Kesehatan Baiturrahim, Jambi \\ ${ }^{2-5}$ Mahasiswa Program Studi Ilmu Gizi, Sekolah Tinggi Ilmu Kesehatan Baiturrahim, Jambi \\ Email: merita_meri@yahoo.com
}

Submitted : 09/04/2020

Accepted: 15/04/2020

Published:16/06/2020

\begin{abstract}
The centred approach of adolescents at school can prevent nutritional problems and improve daily nutrient intake. Therefore, the purpose of this service is the formation of adolescent nutrition posts. This activity was carried out in September 2019 until January 2020, in SMA Negeri 12 of Jambi City. The target is adolescents in the SMA Negeri 12 of Jambi City, who joined student council organizations. This activity consisted of (1) providing counseling with power point media, leaflets, posters, as well as pre-post test questions; (2) Practice monitoring of nutritional status and; (3) Formation of nutrition posts. The outputs of the community service activities are: (1) Effective and innovative leaflets and posters; (2) Application of balanced nutrition in adolescents and; (3) Establishment of adolescent nutrition posts. Based on the pre-test results it was known that the target had good knowledge about balanced nutrition and nutritional status of adolescents ie $>90 \%$ can correctly answer the questions on the post-test sheet. Therefore, it is expected that schools will be able to involve School Health Unit to provide information and health education specifically on the importance of balanced nutrition for adolescents.
\end{abstract}

Keywords: adolescents, nutrition posts

Abstrak
Pendekatan Pos Gizi remaja di sekolah dapat mencegah terjadinya masalah gizi dan memperbaiki asupan zat gizi sehari-hari. Oleh karena itu, kegiatan pengabdian kepada masyarakat bertujuan untuk pembentukan pos gizi remaja. Kegiatan ini dilaksanakan pada September 2019 sampai Januari 2020, di SMA Negeri 12 Kota Jambi. Sasaran adalah remaja di SMA Negeri 12 Kota Jambi, yang tergabung di organisasi OSIS sebanyak 33 orang. Kegiatan ini terdiri dari (1) pemberian penyuluhan dengan media power point, leaflet, poster, serta soal pre-post test; (2) Praktek pemantauan status gizi dan; (3) Pembentukan tim pos gizi remaja. Luaran dari kegiatan pengabdian ini yaitu: (1) Leaflet dan poster yang efektif dan inovatif; (2) Penerapan gizi seimbang pada remaja dan; (3) Terbentuknya pos gizi remaja. Berdasarkan hasil pre-test diketahui bahwa sasaran memiliki pengetahuan baik tentang gizi seimbang dan status gizi remaja yaitu $>90 \%$ dapat menjawab dengan benar pertanyaan pada lembar post-test. Oleh karena itu, diharapkan kepada pihak sekolah untuk dapat melibatkan UKS untuk memberikan informasi dan pendidikan kesehatan khususnya tentang pentingnya gizi seimbang pada remaja.

Kata kunci: pos gizi, remaja

\section{PENDAHULUAN}

Salah satu ciri bangsa maju adalah bangsa yang memiliki tingkat kesehatan, kecerdasan, dan produktivitas kerja yang tinggi. Ketiga hal ini dipengaruhi oleh keadaan gizi. Pola makan merupakan perilaku paling penting yang dapat mempengaruhi keadaan gizi. Hal ini disebabkan karena kuantitas dan kualitas makanan dan minuman yang dikonsumsi akan mempengaruhi tingkat kesehatan individu dan masyarakat.

Faktor yang secara langsung mempengaruhi status gizi adalah asupan makan dan penyakit infeksi. Berbagai faktor yang melatarbelakangi kedua faktor tersebut misalnya faktor ekonomi, keluarga, produktivitas dan pengetahuan tentang gizi anak tersebut. Usia remaja (10-19 tahun) biasanya sangat rentan terhadap masalah gizi, karena pada usia remaja banyak 
mengalami perubahan secara hormonal dan berpengaruh pada perubahan fisiknya (Brown et al., 2011).

Pertumbuhan fisik menyebabkan remaja membutuhkan asupan nutrisi yang lebih besar dari pada masa anak-anak. Ditambah lagi pada masa ini, remaja sangat aktif dengan berbagai kegiatan, baik itu kegiatan sekolah maupun olahraga. Khusus pada remaja putri, asupan zat gizi juga dibutuhkan untuk persiapan reproduksi. Anak remaja yang baru mengalami perubahan hormon maupun fisik biasanya belum terlalu paham dengan perubahan tersebut dan masih dalam tahap proses adaptasi.

Menurut teori Notoatmodjo (2012), kurangnya pengetahuan gizi dapat mengakibatkan, ketidakteraturan perilaku dan kebiasaan makan dapat menjadi penyebab terjadinya masalah gizi. Peningkatan pengetahuan tentang gizi dapat dilakukan dengan program pendidikan gizi yang dilakukan oleh pemerintah. Program pendidikan gizi dapat memberikan pengaruh terhadap pengetahuan, sikap, dan perilaku anak terhadap kebiasaan makannya.'

Pendekatan Pos Gizi Remaja ini memungkinkan remaja di sekolah dapat mencegah terjadinya masalah gizi dan memperbaiki asupan zat gizi sehari-hari. Pos Gizi Remaja ini juga dapat memungkinkan perubahan perilaku gizi yang baik, tidak hanya statis tetapi praktek. Pos Gizi adalah alat menggerakan masyarakat untuk bekerja dengan melibatkan berbagai lapisan sosial di masyarakat tersebut, agar bekerjasama mengatasi masalah dan menemukan solusi dari dalam masyarakat mereka sendiri. Pendekatan ini menitikberatkan pada upaya memaksimalkan sumber daya, keterampilan dan strategi yang ada untuk mengatasi suatu permasalahan dan memanfaatkan metodologi partisipasi secara luas dan proses atau partisipatory learning and action (CORE, 2004). Oleh karena itu, melalui pendekatan model Pos Gizi Remaja ini akan menjadi solusi dalam mengatasi permasalahan gizi remaja.

\section{TARGET DAN LUARAN}

1. Target

Kegiatan pengabdian ini memiliki target khusus yaitu:

a. Adanya siswa/siswi SMA 12 Kota Jambi terlibat dalam kegiatan penyuluhan

b. Adanya partisipasi guru penanggung jawab kelas dalam kegiatan penyuluhan

c. Siswa/i memiliki pengetahuan baik setelah diberikan materi penyuluhan. Indikator pengetahuan baik yaitu jawaban benar pada pertanyaan post test sebesar $\geq 80 \%$.

2. Luaran

Luaran dari kegiatan pengabdian ini yaitu:

a. Leaflet dan poster yang efektif dan inovatif.

b. Penerapan gizi seimbang pada remaja di SMA 12 Kota Jambi.

c. Terbentuknya Pos Gizi Remaja di SMA 12 Kota Jambi.

\section{METODE PELAKSANAAN}

1. Waktu dan Tempat

Kegiatan pengabdian ini dilaksanakan selama 5 bulan pada bulan September 2019 s/d Januari 2020 di SMA 12 Kota Jambi.

2. Tujuan

Tujuan dari kegiatan ini yaitu: (1) Menciptakan materi yang efektif dalam pembentukan pos gizi remaja; dan (2) Remaja di SMA 12 Kota Jambi dapat mentransformasikan prinsip prinsip gizi remaja secara berkesinambungan.

3. Sasaran

Sasaran dalam kegiatan ini adalah remaja di SMA Negeri 12 Kota Jambi, yang tergabung di organisasi OSIS. Total sasaran adalah 33 orang. Adapun kontribusi sasaran dalam pengabdian 
masyarakat ini yaitu menjadi peserta kegiatan pengabdian, mengikuti pre dan post test, dan menjadi fasilitator bagi remaja lainnya.
4. Pelaksanaan Kegiatan Pengabdian Metode dan rincian kegiatan yang akan dilaksanakan dalam program kemitraan ini dirincikan sebagai berikut.

Tabel 1. Metode Pelaksanaan Kegiatan

\begin{tabular}{|c|c|}
\hline Kegiatan & Peserta \\
\hline Persiapan & Tim Pengabdian \\
\hline $\begin{array}{l}\text { Silaturahmi dan } \\
\text { pengembangan } \\
\text { kesepakatan membentuk } \\
\text { Pos Gizi Terpadu }\end{array}$ & $\begin{array}{l}\text { Kepala sekolah, } \\
\text { guru BK }\end{array}$ \\
\hline $\begin{array}{l}\text { Membentuk Pos Gizi } \\
\text { Remaja }\end{array}$ & $\begin{array}{l}\text { Kepala sekolah, } \\
\text { remaja calon } \\
\text { fasilitator }\end{array}$ \\
\hline $\begin{array}{l}\text { Pelatihan Pos Gizi tentang } \\
\text { gizi seimbang pada } \\
\text { remaja }\end{array}$ & Siswa/i \\
\hline $\begin{array}{l}\text { Pelatihan Pos Gizi tentang } \\
\text { PHBS }\end{array}$ & Siswa/i \\
\hline $\begin{array}{l}\text { Pelatihan Pos Gizi tentang } \\
\text { pemantauan } \\
\text { giziremaja }\end{array}$ & Siswa/i \\
\hline \multicolumn{2}{|c|}{$\begin{array}{l}\text { 5. Monitoring dan Evaluasi } \\
\text { Monitoring dan evaluasi (Monev) } \\
\text { dilakukan dengan teknik wawancara dan } \\
\text { obeservasi langsung kepada sasaran. } \\
\text { Cakupan Monev meliputi aspek } \\
\text { perencanaan, pelaksanaan kegiatan, hasil } \\
\text { kegiatan, dan dampak kegiatan. }\end{array}$} \\
\hline
\end{tabular}

\section{HASIL DAN PEMBAHASAN}

SMA Negeri 12 Kota Jambi merupakan salah satu SMA yang terdapat di Kota Jambi. Letak SMA Negeri 12 Kota Jambi sangat strategis karena berada di pusat Kota Jambi dan berada dijalan utama, sehingga cukup strategis untuk menunjang kelancaran kegiatan penyuluhan Pada pelaksanaannya semua siswa/i menghadiri kegiatan sampai selesai sehingga capaian sasaran dalam kegiatan ini $100 \%$. Kegiatan ini didampingi oleh guru kelas sehingga diharapkan dapat mentransformasikan prinsip gizi seimbang dan pengukuran

\begin{tabular}{|c|c|}
\hline Materi & Metode \\
\hline $\begin{array}{l}\text { Langkah kerja, pembagian } \\
\text { tugas, jadwal, Penyusunan } \\
\text { materi dan pemantapan }\end{array}$ & Diskusi Tim \\
\hline $\begin{array}{l}\text { Penyampaian ide, tujuan } \\
\text { kegiatan, membentuk } \\
\text { struktur organisasi, tupoksi }\end{array}$ & $\begin{array}{l}\text { Focus Group } \\
\text { Discussion } \\
\quad(F G D)\end{array}$ \\
\hline
\end{tabular}
penentuan nama calon kader Penyampaian ide, tujuan Diskusi, kegiatan, membentuk musyawah struktur organisasi, tupoksi dan program kerja

Prinsip gizi seimbang, Tutor, tumpeng gizi seimbang, Roleplay, menu gizi seimbang diskusi Prinsip PHBS, penerapan Tutor, PHBS

Roleplay, diskusi

Klasifikasi status gizi, Tutor, penggunaan cakram IMT Roleplay,

status gizi remaja secara

berkesinambungan.

Sebelum dilakukan kegiatan penyuluhan perserta diberikan soal pre-test untuk mengukur pengetahuan awal sebelum diberikan penyuluhan. Pemberian materi disampaikan oleh ketua tim pengabdian serta dibantu oleh 3 orang mahasiswa dalam pelaksanaan teknik pengabdian. Setelah dilakukan penyuluhan, sasaran diberikan soal post-test untuk mengukur pengetahuan sasaran setelah diberikan penyuluhan.

Berdasarkan hasil pre-test diketahui bahwa sebagian besar menjawab salah pertanyaan tentang IMT normal pada remaja $(75,7 \%)$. Kurangnya pemahaman sasaran tersebut dikarenakan kurangnya akses informasi yang diperoleh oleh sasaran baik disekolah maupun ketika sasaran berada diluar lingkungan sekolah. Selain itu, sasaran belum banyak mengenal indikator dalam pengukuran status gizi ideal pada remaja. Pengetahuan yang 
rendah akan berpengaruh kepada perilaku remaja dalam perilaku makan yang tercermin dalam kebiasaan makan atau jajanan sehari-hari yang kurang baik.

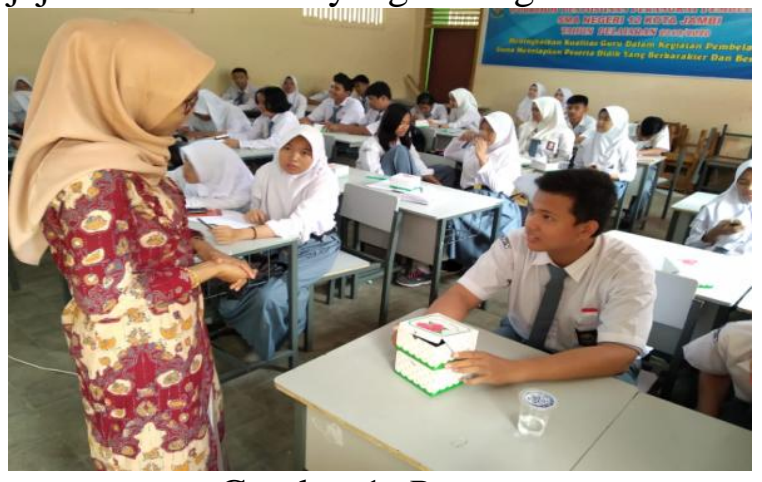

Gambar 1. Pre-test

Status gizi merupakan keadaan kesehatan tubuh seseorang atau sekelompok orang yang diakibatkan oleh konsumsi, penyerapan (absorbsi), dan utilisasi (utilization) zat gizi makanan. Penilaian terhadap status gizi seseorang atau sekelompok orang akan menentukan apakah orang atau sekelompok orang tersebut memiliki status gizi yang baik atau tidak.

Faktor yang secara langsung mempengaruhi status gizi adalah konsumsi pangan dan status kesehatan. Status gizi dapat diketahui dengan beberapa cara yaitu melalui penilaian konsumsi pangan, antropometri, biokimia, dan klinis. Setiap cara penilaian status gizi tersebut melengkapi cara yang lainnya, dengan demikian membantu dalam penyediaan indikator tambahan untuk mendukung penilaian yang lebih lengkap.

Antropometri sudah digunakan pada remaja dalam konteks yang berhubungan dengan status gizi dan kesehatan. Indeks Massa Tubuh (IMT) direkomendasikan sebagai dasar indikator antropometri untuk kekurusan (thinness) dan overweight pada masa remaja. Istilah obesitas dan overweight seringkali dianggap sama. Sebenarnya kedua istilah tersebut tidak sama. Obesitas adalah kondisi kelebihan lemak, baik di seluruh tubuh atau terpusat pada bagian-bagian tertentu, sedangkan, overweight merupakan suatu kondisi dimana perbandingan berat badan dan tinggi badan melebihi standar yang ditentukan. Perbedaan overweight dan obesitas terutama karena perbedaan komposisi tubuh. Obesitas merupakan suatu kelebihan lemak tubuh, sedangkan overweight berkaitan dengan berat badan yang melebihi standar dan tidak selalu berhubungan dengan kelebihan lemak, karena komponen tubuh tidak hanya lemak tetapi juga protein, mineral, dan air.

Pada dasarnya penyebab kegemukan/gizi lebih adalah faktor-faktor seperti psikologis atau psikomotorik, pendidikan dan pengetahuan gizi, aktivitas fisik, kelainan endokrin (hormon), intake makanan yang melebihi kebutuhan, faktor ekonomi, dan keturunan. Intake makanan yang melebihi kebutuhan dapat disebabkan antara lain karena banyak makan ketika menghadapi stress atau depresi dan akibat perilaku/kebiasaan makan yang salah, antara lain ketika memilih makanan, mengolah makanan, kebiasaan ngemil, melupakan makan pagi, makan dengan tergesa-gesa, makan secara berlebihan, frekuensi makan yang tidak teratur, dan terkadang menghindari nasi.

Salah satu sumber bahan pangan yang baik untuk memperoleh zat gizi adalah buah dan sayur. Buah dan sayur disarankan untuk dikonsumsi oleh seseorang dalam piramida kesehatan. Konsumsi buah dan sayuran dapat mencegah kejadian obesitas karena dapat mengurangi rasa lapar dan tidak menimbulkan kelebihan lemak dan sebagainya. Buah dan sayur dapat menjadi makanan selingan yang sangat baik karena mengenyangkan rendah lemak, serta kaya akan vitamin yang diperlukan oleh tubuh 


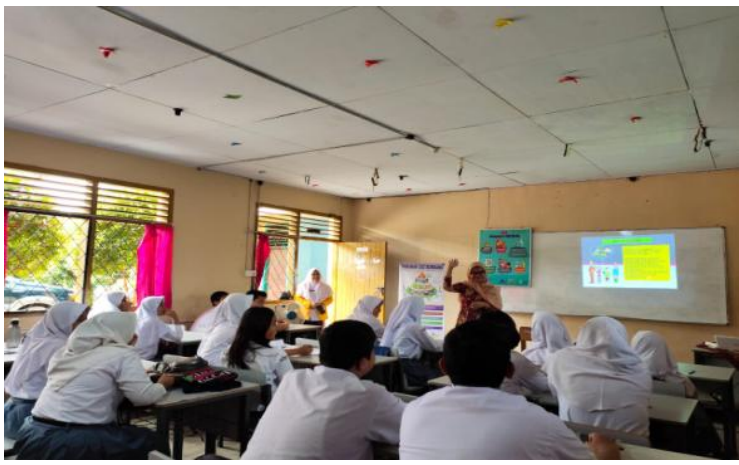

Gambar 2. Kegiatan Penyuluhan Gizi Remaja dan Pos Gizi Remaja

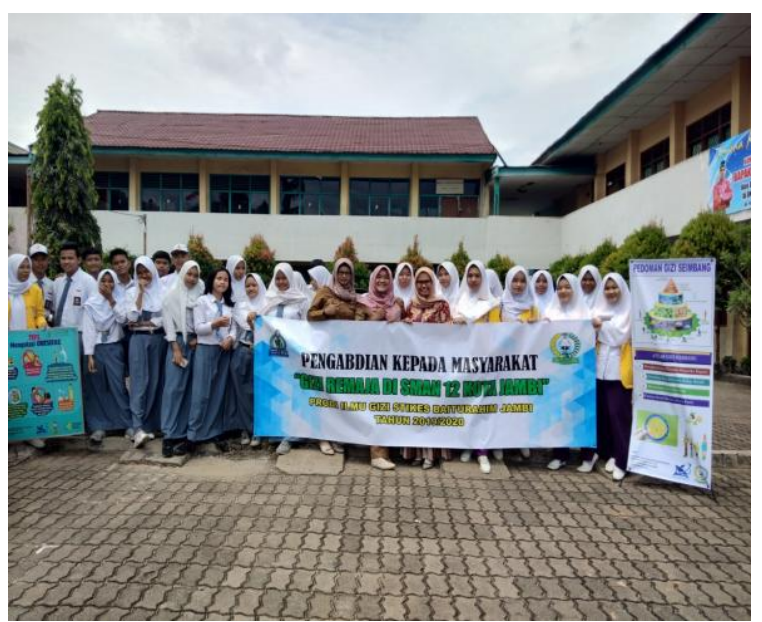

Gambar 3. Kegiatan Pembentukan Pos Gizi Remaja

Setelah diberikan penyuluhan terjadi peningkatan pengetahuan pada sasaran. Hal ini ditandai dengan rerata skor post test pada sasaran meningkat sebesar 1,7 poin. Hasil post test menunjukkan peningkatan pengetahuan dimana sasaran dapat menjawab dengan benar pada masingmasing pertanyaan post test. Hal ini ditunjukkan pada hasil dimana sasaran mampu menjawab dengan benar pertanyaan tentang IMT normal pada remaja $(98,3 \%)$, porsi konsumsi buah dan sayur dalam sehari (98\%), dan porsi konsumsi protein hewani dan nabati dalam sehari (96\%). Hasil ini sejalan dengan kegiatan pengabdian oleh Junita et al., (2020) pada kader gizi yang menunjukkan bahwa skor pada saat pre-test tergolong rendah namun setelah dilakukan penyuluhan gizi terjadi peningkatan untuk setiap skor responden. Peningkatan skor ini dikarenakan adanya pengaruh informasi yang telah diterima oleh kader pada saat kegiatan penyuluhan. Demikian pula, hasil penelitian Fauziah (2012) yang menunjukkan bahwa ada perbedaan bermakna pada pengetahuan, sikap dan praktik sebelum dan sesudah dilakukannya edukasi.

Pengetahuan adalah merupakan hasil "tahu" dan ini terjadi setelah orang mengadakan penginderaan terhadap suatu objek tertentu. Penginderaan pendengaran, penciuman, rasa dan raba dengan sendiri. Sebagian besar pengetahuan manusia peroleh melalui mata dan telinga (Notoatmodjo, 2011). Kegiatan pengabdian ini menggunakan media yang sesuai dengan kebutuhan responden sehingga mampu membangkitkan indera untuk mentransformasikan informasi tersebut menjadi sebuah pengetahuan. Pengetahuan yang lebih baik diharapkan responden mampu membuat sikap yang lebih baik pula terhadap pernyataan yang diberikan seputar jajanan sehat pada anak usia sekolah.

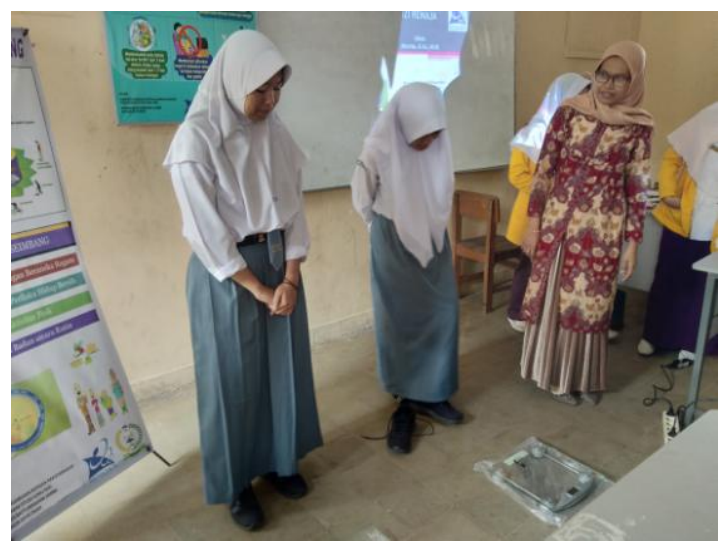

Gambar 4. Praktik Pemantauan Status Gizi Remaja (IMT/U)

Pada pelaksanaan kegiatan ini, tim pengabdian juga mempraktikkan cara menggunakan cakram IMT pada remaja, menghitung status gizi remaja dengan indikator IMT/U, serta memilih "siswa/i melek gizi". Pada pelaksanaanya, sasaran merespon dengan baik sehingga ada feed back antara pemateri dengan sasaran. Hasil kegiatan ini mendapatkan sebanyak 3 orang siswa (dari 20 siswa/i) terpilih menjadi 
"siswa melek gizi" karena dapat mempraktekkan cara menggunakan cakram IMT, menghitung status gizi dengan baik dan benar, serta dapat menjelaskan kembali prinsip pedoman gizi seimbang.

\section{KESIMPULAN DAN SARAN \\ 1. Kesimpulan}

Berdasarkan kegiatan pengabdian masyarakat yang dilakukan, maka dapat disimpulkan bahwa tingkat partisipasi dan kehadiran sasaran sangat baik yaitu $100 \%$. Selain itu, sasaran memiliki pengetahuan baik tentang gizi seimbang dan status gizi remaja yaitu > 90\% dapat menjawab dengan benar pertanyaan pada lembar posttest.

\section{Saran}

Diharapkan kepada pihak Sekolah dapat melibatkan Unit Kesehatan Sekolah (UKS) untuk memberikan informasi dan pendidikan kesehatan khususnya tentang pentingnya gizi seimbang pada remaja. Selain itu, perlu upaya kerja sama dari pihak sekolah dengan Puskesmas setempat dalam penyediaan sarana informasi seperti poster, leaflet yang menunjang dalam penyampaian informasi tentang kesehatan dan gizi di lingkungan sekolah.

\section{UCAPAN TERIMAKASIH}

Terimakasih disampaikan kepada Sekolah Tinggi Ilmu Kesehatan Baiturrahim yang telah memberikan dukungan dana sehingga kegiatan ini dapat terlaksana dengan baik. Selain itu, Terimakasih disampaikan kepada pihak sekolah SMA 12 Kota Jambi yang telah bersedia menjadi target kegiatan pengabdian ini.

\section{DAFTAR PUSTAKA}

Almatsier, S. 2008. Prinsip Dasar Ilmu Gizi. Jakarta : Gramedia Pustaka Utama.

Brown, Judith et al. 2011. Nutrition Through Lyfe Cycle. USA: Thomson
W.

CORE. 2004. Positive deviance \& Hearth: Suatu pendekatan perubahan prilaku dan pos gizi. Jakarta: PCI Indonesia (terjemahan), Jejaring positive Deviance Indonesia

Fauziah. 2012. Pengaruh Pendidikan Kesehatan Tentang Nutrisi Prakonsepsi Terhadap Tingkat Pengetahuan, Sikap, dan Praktik Konsumsi Makanan Sehat Wanita Pranikah. Tesis.Jakarta : Universitas Indonesia.

Junita, D., Merita, M., \& Armina, A. (2019). Pembentukan Dan Pelatihan Kader Posdaya Tentang Skrining Kesehatan Dasar Di Desa Bungku Kecamatan Bajubang Kabupaten Batanghari Jambi. LOGISTA-Jurnal Ilmiah Pengabdian kepada Masyarakat, 3(2 (Jul-Des)), 27-38.

Notoatmodjo, S. 2012. Promosi Kesehatan dan Perilaku Kesehatan. Jakarta: PT Rineka Cipta. 